\title{
Approach on Milk yield of Buffalo Herds
}

Taís Casonato Rodrigues, Cecílio Viega Soares Filho, Iveraldo dos Santos Dutra and Katia Denise Saraiva Bresciani*

Universidade Estadual Paulista (Unesp), Faculdade de Medicina Veterinária, Brasil

Received: 筁 August 15, 2018; Published: 制 August 20, 2018

*Corresponding author: Bresciani KDS, Departamento de Apoio, Produção e Saúde Animal, Universidade Estadual Paulista (Unesp), Faculdade de Medicina Veterinária, Araçatuba, São Paulo, Brasil

\begin{abstract}
Buffalo herds are an important part of the agricultural economy but, unfortunately, this production chain is still not valued as such in some countries, presenting yields lower than expected. This review of the literature aims at discussing the importance of buffalo herds for the milk production in several countries and the need for increasing the production yields of this species. Buffaloes are even more important for the economies of developing countries, where the economic activity is based primarily on agriculture as in some Asian countries. Although all buffalo parts can be commercially explored, buffalo milk derivatives are the most profitable. Therefore, maximizing the yields of both meat and milk is highly desirable.
\end{abstract}

Keywords: Buffaloes; Milk; Production

\section{Introduction}

Buffalo breeding is a highly important economic activity where it is practiced since buffalo farms employ rural labor, decreasing rural exodus and increasing the exploration of areas previously considered unsuitable for agricultural production Bernardes [1] Buffaloes are increasingly raised for the meat and hides since the meat has high protein content Andrighetto [2], Bernardes [1]; Nanda; Nakao, [3] and fatty acids of lower atherogenicity Bernardes [1]. In addition, leather, horns, and horsehair are used by the industry and in handicraft work Nanda and Nakao, [3]. Also, buffalo milk has excellent organoleptic quality and its high addedvalue makes dairy production highly profitable Nanda, Nakao [3]; Bernardes, [1]; Andrighetto, [2]; Borghese [4]. Finally, buffaloes are used as animal traction for works in the field Nanda, Nakao [3] while dry buffalo manure can be used to generate energy Ferreira [5]. This literature review aims at discussing the importance of buffalo breeding in several countries and the need for productivity increase of this species.

\section{Literature Review}

There are approximately 168 million buffaloes in the world, of which 161 million in Asia (95.83\%), 3.717 million in Africa, almost entirely in Egypt, 3.3 million (1.96\%) in South America, 40.000 in Australia (0.02\%), and 500.000 in Europe (0.30\%) Borghese [6]. The economy of most Asian countries is based on agriculture, with approximately $60-80 \%$ of the population working in rural activities, especially cattle raising. Buffaloes are very important in this scenario for producing milk, meat, and leather, and for working as animal traction in the fields for thousands of years Nanda, Nakao [3] while also contributing to the environment by providing organic fertilizer obtained from the dry manure Ferreira [5]. Buffaloes are essential for the socio-economic development of developing countries, especially for the small producers in Asia. Buffaloes are raised for milk production in southern Asia, and animal traction in the east, being also suitable for milk and meat production. The Asian buffalo herds may be easily expanded, especially due to the incentive and support received from the national and international development agencies Nanda, Nakao [3].

The buffalo population increased $14.7 \%$ in Pakistan between 1996 and 2001 and it is likely to continue growing. Pakistan ranks seventh in the ranking of milk-producing countries. This country has great breed diversity for high milk yield and well adapted to the environmental conditions. Buffalo milk plays an important role in agricultural development, discourages migration to urban areas by increasing rural employment Memon, Khushk [7]. In Sindh, a province of Pakistan, although buffalo milk (66\%) is predominant, yield could be higher, if problems such as food shortages, inferior animal genetics, high mortality rate, high input costs, lack of hygienic sanitary conditions, difficult product commercialization 
in the consumer markets, shortage of skilled labor, financial constraints, and breeder disorganization could be controlled or mitigated Memon, Khushk [7]. In the Mediterranean region, which covers Europe and countries in the Middle East, the buffalo population has decreased in countries such as Bulgaria, Romania, Turkey, and Iran and increased in Italy, Germany, and Egypt. The buffalo population increase observed in the last countries is due to the strong consumer market for products derived from buffalo milk, associated with culinary and cultural traditions, in addition to the high taxes imposed on the cattle herd by the European Union. On the other hand, the buffalo population decrease observed in the first group of countries is related to rural mechanization, the inexpressive market for buffalo products Borghese [4], increasing industrialization and demand for meat, and non-replacement of slaughtered animals Borghese [6]. In China, the buffalo milk industry is growing with great potential for developing and becoming a strong pillar in the agricultural expansion and rural economy of the country Yang [8].

In order to avoid the decrease of the buffalo population observed in some countries in Europe and the Middle East, a few preventive steps are required such as determining the market demand for buffalo products, improving feeding and reproductive management by using high quality semen, and developing/using modern technologies for meat and milk processing Borghese [4]. India houses 95 million buffaloes, $56.5 \%$ of the world buffalo population, ranking first in buffalo milk production in the world with 134 million tons. It is also the most prosperous country in Asia regarding buffalo development from the viewpoint of science and technology, production, reproduction, nutrition and breeding (Borghese, 2005). In the 19th century, about 200 buffaloes originating from Asia, the Caribbean and Europe, especially Italy, were introduced in Brazil. The herd increased to 495,000 buffaloes in 1980; the annual growth of $10.86 \%$ between 1961 and 1980 demonstrates the great adaptive capacity of the species Bernardes [1]. Between 2010 and 2011, the buffalo population increased $7.8 \%$, especially in the North and Northeast regions Ferreira [5]. The largest buffalo population in the country with 520 thousand animals is observed in Para Ibge [9].

Currently, the buffalo population consists of approximately three million animals, 30\% of which are destined for milk production, according to the Brazilian Association of Buffalo Breeders (Associação Brasileira dos Criadores de Búfalos-ABCB).The national production of buffalo milk is 92.3 million liters, of which 45 million are processed into 18.5 thousand tons of dairy products, being a good source of revenue for dairy farmers and breeders Bernardes [1]. The meat production chain is less expressive compared to milk; however, its commercialization is underestimated since buffalo meat is often sold as cattle Andrighetto [2]. Although not much has been invested in the genetic improvement of the species, buffalo herds have grown over theyears, a trend that is expected to continue in much of the world. The optimization of buffalo performance requires new technologies, such as using artificial insemination with high-quality animal semen, leading to genetic improvement; improving feed management and quality; training specialized labor Memon, Khushk [7] Andrighetto [2]. Furthermore, a legislation for the production of milk and high-quality derivatives should be elaborated as to increase the competitiveness of the consumer market, including the external market Andrighetto [2].

\section{Conclusion}

Buffaloes are very important for the economies of developing countries, where the economy is largely based on agriculture, as in some Asian countries. Although all buffalo parts can be used and commercialized, the milk derivatives are the most profitable. Therefore, maximizing the yields of both meat and milk are highly desirable [10].

\section{References}

1. Bernardes 0 (2007) Bubalinocultura no Brasil: situação e importância econômica. Rev Bras Reprod Anim 31(3): 293-298.

2. Andrighetto C (2011) Cadeia produtiva do leite de búfala: visão da universidade. In: Simpósio da cadeia produtiva da bubalinocultura. International symposium of buffalo production chain, Botucatu. Anais. Botucatu: FEPAF.

3. Nanda AS, Nakao T (2003) Role of buffalo in the socioeconomic development of rural Asia. Animal Science Journal 74(6): 443-455.

4. Borghese A (2010) Development and perspective of Buffalo and Buffalo market in Europe and Near East.

5. Ferreira AMC, Marcondes CR, Brito lg, Costa CM, Andréas MV, et al. (2012) Descrição dos níveis de produção dos rebanhos de búfalas leiteiras nas regiões norte e nordeste. Anais da VI Jornada Científica Embrapa São Carlos.

6. Borghese A (2005) Buffalo Production and Research. Reu Technical Series 67: 2-35

7. Memon A, Khushk, AM (2004) Economic analysis of buffalo dairy farms in Sindh. Indus Journal of Biological Sciences 2: 231-240.

8. Yang BZ, Liang XW, QIN J, YANG CJ, Shang JH (2013) Brief introduction to the development of Chinese dairy buffalo industry. Buffalo Bulletin 32: $111-120$.

9. Instituto brasileiro de geografia e estatística (IBGE) (2016) Maior concentração de búfalos no país, Ilha de Marajó está no Censo Agro.

10. Pereira RGA, Costa NL, Towssend CR, Magalhães JA (2007) Produção de leite de búfalas na agricultura familiar em Rondônia. 
(c) (1)

This work is licensed under Creative

Submission Link:

Commons Attribution 4.0 License

DOI: $10.32474 /$ CDVS.2018.01.000124

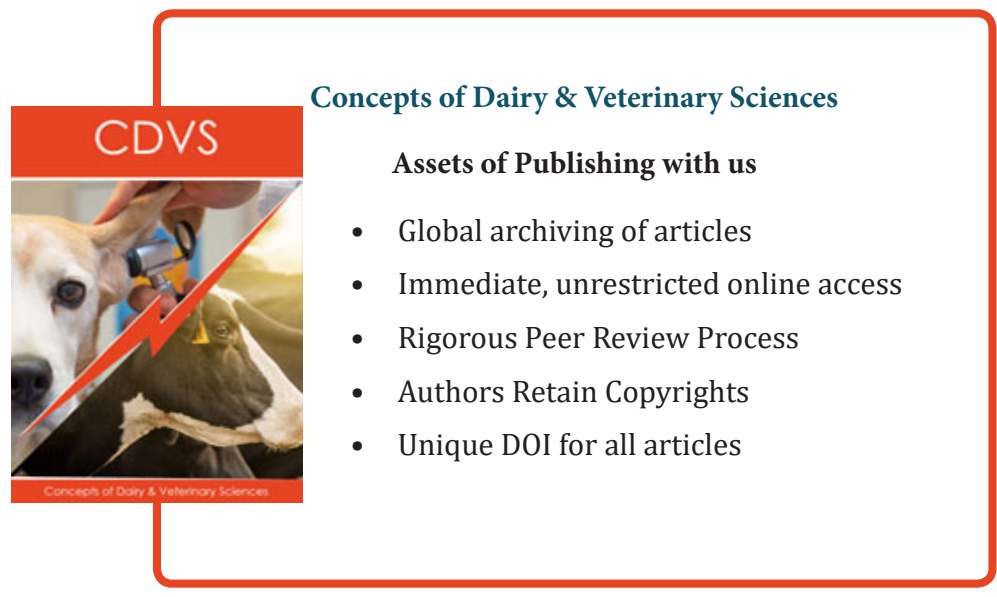

